\title{
Skill Issues for Islamic Financial Institutions-Reasons and Solutions
}

\author{
Shamsalden Aziz Salh* Yousif Ameen Mohammed \\ Soran University, Faculty of Law, Political Science and Management, Law Department
}

\begin{abstract}
This study focuses on the skill issues of the Islamic financial institutions that impact on the industry negatively. For the Islamic financial industry to develop according to the standard level, it needs proper skills. Therefore, this paper clarifies the issue first and then reasons for skill gaps in the Islamic financial industry. Shortage of centers and training courses for creating talents in Islamic finance field slows down the industry. In addition, the current unqualified staff of Islamic financial institutions effect on the Islamic financial industry. Shortage of skills in the Islamic finance field is not always due to the insufficient number of staff, but because that current staff do not possess all related Islamic financial knowledge, such as legal, Shariah and modern finance system. Therefore, this paper presents suitable methods for developing and producing Islamic finance professionals. Establishing centers and colleges for producing knowledgeable Islamic financial staff is an important method for developing the Islamic financial industry. In addition, opening training courses by Islamic financial institutions can also be a good tool for developing necessary skills of the current Islamic financial employees.
\end{abstract}

Keywords: Islamic Finance, Skill Issues and Islamic Financial Institutions

DOI: $10.7176 /$ JLPG/89-14

Publication date:September $30^{\text {th }} 2019$

\section{1- Introduction}

Islamic financial industry is developing rapidly and it needs new skills for running Islamic financial business. However, the number of skills for Islamic finance in the world is less than required. Such insufficient number of skills for the Islamic finance industry affect its business. Therefore, there should be a solution to the issue for Islamic finance institutions to provide the best products for their customers. When Islamic finance first appeared in the 1970s the majority of bankers working in these new institutions came from a conventional finance background. In addition, the Sharia scholars at the time did not have sufficient experiences compared to the expertise and knowledge they have today. ${ }^{1}$ However, it does not mean that Islamic financial institutions already have enough skills today.

In fact, there are reasons for the skill gaps of Islamic finance in the world which hamper the development of these institutions. One possible reason is that there are not enough academics for teaching in the field of Islamic finance. Furthermore, the shortage of colleges and centers for educating Islamic financiers could be another reason. In that context, this paper analyzes these possible reasons and then offer effective solutions to fill skill gaps in the Islamic financial industry. The study will refer to some countries that have long experience in practicing Islamic finance and have abilities in resolving Islamic financial institutions' skill gaps.

\section{2- Impact of Shortage of Talents on Islamic Financial Institutions}

Islamic financial industry has a problem of talent that there is a huge shortage of suitably skilled employees working within the industry. ${ }^{2}$ Such shortage has an impact on financial institutions. For the development of the sector, there should be numbers of skills that need to be trained and educated about Islamic finance. To be clear what type of skills are needed for the Islamic financial institutions in general, the qualifications should be specified. The key talent shortages in Islamic finance pertain mainly to technical and Shariah knowledge; as well as more general skills such as product innovation and strategic planning. It is noted clearly that industry practitioners regard the development of training programs in Islamic finance as being somewhat effective in supporting the needs of Islamic financial institutions. ${ }^{3}$

In case of lacking or shortage of talents in the Islamic financial sector, the growth of the sector will be slowed down. In addition, skill gaps in Islamic financial institutions waste the institution's time and incur a cost. Moreover, the institutions may lose their customers due to these skill gaps. Accordingly, it will eventually cause the industry to lose its market. In general, clients expect a high quality of services from the institution. In fact,

\footnotetext{
1 Gulf News Business,' Bridging the skills gap in Islamic finance'Tirad Al-Mahmoud, January 2016, (https://gulfnews.com/business/banking/bridging-the-skills-gap-in-islamic-finance) acceessed 3 January 2019.

2 Chartered Institute of Management Accountant, "An Introduction to Islamic Finance" 2014, (https://www.cimaglobal.com/Documents/Islamic\%20finance/Rebrand\%20Brochures/Islamic\%20Introduction\%20brochure_Mar2015.pdf) accessed 17 March 2019.

${ }^{3}$ Malaysia World's Islamic Finance Marketplace, 'GROWING DEMAND FOR TALENT IN ISLAMIC FINANCE' June 2015, (http://www.mifc.com/index.php?ch=28\&pg=72\&ac=133\&bb=uploadpdf) Accessed 8 March 2019.
} 
high-quality services are provided by the Islamic financial institution that has skillful and experienced staff. If the institution has a problem of proper employees and managers then it cannot provide proper services. Therefore, skill gaps in Islamic financial institutions make the institutions face a big challenge as the issue reduces the quality of the products and transactions offered by the institutions.

\section{2-1- Slow Down Development of the Institution}

Shortage of skills in Islamic financial institutions slows down the development of the institutions. It is clear that developing any sector or any company needs proper human capital. In that context, there is an increasing worldwide demand for skills as Islamic finance expands. ${ }^{1}$ Skilled talents assist the institution to manage all the jobs in a better way. Islamic financial institutions should compete with conventional financial institutions to win this competition. Hence Islamic financial institutions need skillful people. Having insufficient Islamic financial skills has a negative impact on the growth of the Islamic financial institutions, which is obviously a disadvantage as compared to their conventional counterparts. Most of the skills in the Islamic financial sector suffer from a lack of knowledge about Islamic financial products. Therefore, the shortage of skills in the sector can be one of the obstacle and challenge for the development of the Islamic financial sector in general. The Islamic financial services industry is a much-specialized field and obtaining the right capabilities and skills sets is critical. A lack of qualified Islamic finance graduates with the required talents by the industry could affect industry growth. ${ }^{2}$

"According to Al Meezan Investments CEO Mohammad Shoaib, the existing structure is already thirsty for sales team trained in basic concepts; he puts the figure for potentially skilled staff required at over 1,000. To support this growth, an additional $80-90$ highly skilled people will be required to take the industry to the next level of maturity." 3

\section{2-2- Wasting of the Time and the Cost}

Skill gaps in Islamic financial institutions cause the industry to waste money and also the time. Sometimes because that the industry or the Islamic financial institution needs to make a decision about a contract or a transaction while the employees of the institution do not have enough knowledge about the transaction, the institution needs to hire outside professionals to make the right decision. In this case, the Islamic institution loses its money and time as these professionals should be paid and it also takes more time for the contract to be made. Some Islamic financial institutions need to depend on private firms to borrow skills from in order to fill the gap of lacking skills. Those firms provide advice to any Islamic financial institution in Shariah aspects. Islamic financial institutions should pay the firms to obtain advice for their employees about any contract or any issue that the institution is faced. In fact, the process of acquiring advice from the Sharia advisory firm takes longer time other than incurring the cost of the Islamic financial institution. Therefore, skill gaps of the Islamic financial institutions delay the process of transactions that are conducted by the institutions. As a result, the income of the Islamic financial institution will be reduced and the cost of the products will be increased. In addition, providing training courses by any Shariah advisory firm for the staff will cost the institutions. It can be said that the collected knowledge in the industry, could have serious cost effects for the industry. ${ }^{4}$

\section{3- Reasons behind Skill Gaps In Islamic Financial Institutions}

There are many reasons behind skill gaps in the Islamic financial industry.

\section{The industry is new.}

One reason is that this industry is still young. The Islamic financial industry started operating in its modern form in the 1970s, and in numerous countries has only become a mainstream industry in the past decade. The industry has moved into relatively complex areas, such as Islamic money market instruments and hybrid Islamic bonds with equity-linked characteristics, only in recent years. ${ }^{5}$

Therefore, the staff of the Islamic financial industry is still at the early stage when it comes to knowledge compared to the traditional financial sector. As the Islamic financial sector started its operation in the 1970s, the staff and managers of the sector are lack of knowledge in Islamic financial business. Most of its staff come from

\footnotetext{
1 Chris Cummings, (2015) ,The UK: Leading western Centre for Islamic Finance, ' The UK Islamic Finance Market' (https://www.londonstockexchange.com/specialist-issuers/islamic/islamicfinance2015.pdf) Accessed 17 March 2019.

2 Finance Accreditation Agency, 'Issues and Challenges in Developing Human Resources in Islamic Finance' (https://www.faa.org.my/article/issues-and-challenges-in-developing-human-resources-in-islamic-finance) accessed 6 March 2019.

${ }^{3}$ Dawn, 'Gaping HR gap in Islamic finance industry' Sarwat Ahson, January 2016, (https://www.dawn.com/news/1230681) accessed 6 March 2019.

${ }^{4}$ Sayd Farook and Mohammad Omar Farooq, (2013) 'Sharôñah Governance, Expertise and Profession: Educational Challenges in Islamic Finance' ISRA International Journal of Islamic Finance, 5, 1, P 143.

5 Al-Zaquan Amer Hamzah, 'Training gap overshadows Malaysia's Islamic finance growth' October 2013, (https://www.reuters.com/article/islamic-finance-education/training-gap-overshadows-malaysias-islamic) accessed 7 March 2019.
} 
the conventional financial sector when the industry started to open and establish at the beginning. ${ }^{1}$ Therefore, the Islamic financial industry and its staff are young and still have the problem of lacking skillful employees and managers.

\section{Insufficient number of education centers for Islamic finance}

Lack of a sufficient number of colleges and centers for education in Islamic finance is considered as another reason behind skill gaps in the industry. There are some centers and colleges that offer courses in Islamic finance in the world. However, the number of these centers and universities is fewer as compared to the number of financial institutions in the world. Some countries maybe have a sufficient number of universities and colleges and centers that offer Islamic financial courses, such as Malaysia and Bahrain. But in general, the number of colleges and centers in the world is still not enough to meet the demand of the industry. In addition, the courses and subjects that are studied in these centers or universities may not help produce proper knowledgeable and skillful employees for the Islamic financial institutions. Therefore, not only a shortage of courses and centers that offer Islamic financial degrees but also the lacking of qualified courses are the cause of the issue of skill gaps in Islamic financial institutions. In this sense, qualified courses help produce qualified staff and employees for the industry to develop, grow and compete with traditional financial institutions.

\section{Non-Qualification of the courses}

There are some courses that should be studied by students who take Islamic financial course. Shariah, modern economics, finance, legal courses are important to be taken for any student to take Islamic finance courses. Thus, besides the Shariah aspect, other knowledge should be taught at any center that produces Islamic finance staff. However, most of the centers and universities that offer Islamic financial course do not teach students all these courses. Therefore, graduated students are not qualified to work and serve in Islamic financial institutions. Most of the Islamic financial institutions looking for those staff who have all these aforementioned knowledge.

In addition to the courses about Islamic finance, working experience is vital for taking part in the Islamic financial industry. Most of the Islamic financial institutions look for knowledgeable and experienced skills for their institutions. The institutions do not want to spend money on educating their new and freshly graduated students. ${ }^{2}$ Moreover, these institutions do not spend their time training their staff. Therefore, cost and time are two important elements for the Islamic financial institutions to develop their products.

Hence, the lack of Islamic financial skill does not mean that there is not new graduation in the field sometimes. Furthermore, there may be numbers of students graduate every year in the field of Islamic finance, but they do not have practical skills. They studied many subjects about Islamic finance in theory, but they did not practice in the field. Thus, it could be said that lack of cooperation between the academia and Islamic finance industry to develop a wholesome curriculum in Islamic finance has resulted in a mismatch between the graduates produced and the skills required by the industry. Graduates go through a system which is more theoretical than practical are not suitably equipped for the industry. ${ }^{3}$ Fresh graduate students must take some practical training courses in Islamic finance during or right after graduation, due to the reason that fresh graduates must compete with the experienced workers in the industry. ${ }^{4}$

\section{4- Solutions for the Skill Gaps In Islamic Financial Institutions}

Talent development solutions may go beyond the circle of the financial services community, to include other business communities, such as legal community, government officials and IT solution providers. The development of the Islamic financial sector also relies on these parts of the private and public sectors. Their training needs must also be met through structured training programs to facilitate their understanding of the specifics of Islamic finance and its value propositions. Establishing centres and institutions to produce qualified Islamic financial skills is an important solution to mitigate the negative impact of skills gaps. There are several important centres in the world that can help the Islamic financial institutions in creating new and qualified skills for the industry.

The International Centre for Education in Islamic Finance (INCEIF) was established in 2006 to develop qualified professionals in Islamic finance. ${ }^{5}$ The International Shariah Research Academy for Islamic Finance (ISRA) in Malaysia is another important education center for producing Islamic financial talents. These centers have been gaining more and more worldwide recognition in producing talents and meeting research needs to

\footnotetext{
${ }^{1}$ Naoel Chaouch, (2017), 'An Exploratory Study of Tunisian Customers' Awareness and Perception of Islamic Banks' International Journal of Islamic Economics And Finance Studies, 3, 2, p 28.

${ }^{2}$ Siti Khadijah Ab Manan, Rafeah Saidon, Amal Hayati Ishak, and Noorul Huda Sahari, 'COMPETENCY SKILLS OF GRADUATING ISLAMIC FINANCE STUDENTS' (2018) The Turkish Online Journal of Design, Art and Communication, 1424.

3 Finance Accreditation Agency, 'Issues and Challenges in Developing Human Resources in Islamic Finance' (https://www.faa.org.my/article/issues-and-challenges-in-developing-human-resources-in-islamic-finance) accessed 6 March 2019.

${ }^{4}$ Nurul Wajhi Ahmad, Murni Yunus Mawar, and Norazlina Ripain, (2017) 'The Exploration Study on Employability of Islamic Banking and Finance Graduates' Proceeding of the 4th International Conference on Management and Muamalah 2017 (ICoMM 2017 ), 641.

${ }^{5}$ Zeti Akhtar Aziz, 'Talent development in Islamic finance over the next decade' (2011) KL (https://www.bis.org/review/r111222h.pdf) accessed 17 March 2019.
} 
support the growth of the vibrant industry. ${ }^{1}$ Some countries established special centers for producing Islamic financial skills and opened training courses for their current staff of Islamic financial institutions, e.g. Malaysia. The Bank Negara Malaysia, which is Central Bank of Malaysia, has been working hard on developing Islamic financial skills. As a result, Malaysia is estimated to have 50-course providers and 18 universities, which offer Islamic finance degrees, and it provides the largest academic output internationally. The country has published 169 research papers on Islamic finance in the last three years, according to data from Thomson Reuters. Although the Malaysian Islamic banking industry's output in monetary terms is growing about 20 percent annually, employment in it is expanding at less than half than that rate, which is happening in the context that an additional 22,400 jobs are needed to support the growth, according to a blueprint for the financial sector prepared by the central bank. ${ }^{2}$

In addition, Islamic financial institutions could provide some specialized training for their current staff. ${ }^{3}$ Nonetheless, banks have so far been unwilling to do so because of the time and cost involved. Instead, they tend to poach skilled staff from rivals, a quicker and cheaper alternative way of acquiring talents needed. In fact, the current staff of Islamic financial institutions are lack of knowledge in Islamic financial products. ${ }^{4}$ Therefore, they need to update their knowledge and information about Islamic financial transactions and products. Opening monthly or quarterly training courses for the current staff is necessary.

Moreover, it is important for Islamic financial institutions to establish a strong relationship with universities and colleges that produce proper skills for these institutions. In that context, it can be seen that in a country like Hong King some large international banks have also developed close partnerships with leading universities to develop specific banking courses designed to provide students with an understanding of practical banking operations. $^{5}$

Hence, to develop talent skills and fill the skill gaps, Islamic financial institutions can request universities and colleges that offer Islamic financial courses to design some specific courses and subjects that produce special talents in the Islamic finance field. In addition, these colleges and universities can teach their students courses related to Islamic finance in theory while the Islamic financial institutions can provide practical training courses to those students. The summer school programs for students in Islamic finance that focus on practical aspects of Islamic finance through business operation simulations can also be a good option. ${ }^{6}$ In that logic, the graduated students from those universities can have both practical and theoretical skills in running Islamic financial business. Ultimately, Islamic financial institutions will be able to acquire trained and skillful staff.

\section{5- Conclusion}

For the Islamic financial industry to develop faster and to compete with its conventional counterpart, it needs a sufficient number of skills. Trained and experienced staff is necessarily needed. Therefore, Islamic financial institutions are looking for professionals skills. The skill gaps in the Islamic financial industry slowdown the development of the industry. There are many reasons for these skill gaps. An insufficient number of training centers and colleges for producing Islamic financial skills is a serious reason for lack of Islamic finance professionals. The current inexperienced staff of Islamic financial institutions is another reason behind skill gaps in the industry. In addition, the Islamic financial industry does not provide enough fund for training their staff and fresh graduates. Furthermore, freshly graduated students have only theoretical knowledge without practical experiences.

For resolving the issue of skill gaps in the Islamic financial industry, there should be quarterly training courses for the current Islamic financial staff. Hence, Islamic financial institutions should provide a fund for this purpose. Opening colleges and centers for producing talent in the Islamic financial industry is another important method. Reforming in the provided courses could also be a solution. The courses that are offered by training centers and universities in Islamic financial degrees should include subjects on Shariah, law, modern economy, accounting, and conventional banking system. As a result, these universities and centers can produce professionals demanded by the Islamic financial system. Moreover, there should be a strong relationship between Islamic financial institutions and universities. The two should work together to provide practical courses

\footnotetext{
${ }^{1}$ Asian Banking Finance, 'Islamic banks struggle with talent dearth as professionals lack full competency in Shariah' STAFF REPORTER, MALAYSIA (https://asianbankingandfinance.net/islamic-banking/exclusive) accessed 5 March 2019.

2 Al-Zaquan Amer Hamzah, 'Training gap overshadows Malaysia's Islamic finance growth' October 2013, (https://www.reuters.com/article/islamic-finance-education/training-gap-overshadows-malaysias-islamic) accessed 7 March 2019.

${ }^{3}$ Norhanim Dewa and Sabarudin Zakaria, (2012), 'Training and Development of Human Capital in Islamic Banking Industry' Journal of Islamic Economics, Banking and Finance, 8, 1, p 99.

${ }^{4}$ Tengku Wasimah Raja Harun, Rosemaliza Ab Rashid, and Abu Bakar Hamed, (2015) Factors Influencing Products' Knowledge of Islamic Banking Employees' Journal of Islamic Studies and Culture, 3, 1 p 25.

5 Institute Bank-Bank of Malaysia, 'Study on talent and skills requirements for the banking sector in Malaysia' June 2014, (https://www.pwc.com/my/en/assets/publications) accessed 8 March 2019.

${ }^{6}$ Zeti Akhtar Aziz, 'Talent development in Islamic finance over the next decade' (2011) KL (https://www.bis.org/review/r111222h.pdf) accessed 17 March 2019.
} 
and training for the graduated and current students so that the graduated students can have both practical and theoretical experiences in Islamic finance.

\section{References}

1- Al-Zaquan Amer Hamzah, 'Training gap overshadows Malaysia's Islamic finance growth' October 2013, (https://www.reuters.com/article/islamic-finance-education/training-gap-overshadows-malaysias-islamic) accessed 7 March 2019.

2- Al-Zaquan Amer Hamzah, ‘Training gap overshadows Malaysia's Islamic finance growth' October 2013, (https://www.reuters.com/article/islamic-finance-education/training-gap-overshadows-malaysias-islamic) accessed 7 March 2019.

3- Asian Banking Finance, 'Islamic banks struggle with talent dearth as professionals lack full competency in Shariah’ STAFF REPORTER, MALAYSIA (https://asianbankingandfinance.net/islamic-banking/exclusive) accessed 5 March 2019.

4- Chartered Institute of Management Accountant, "An Introduction to Islamic Finance" 2014, (https://www.cimaglobal.com/Documents/Islamic\%20finance/Rebrand\%20Brochures/Islamic\%20Introduct ion\%20brochure_Mar2015.pdf) accessed 17 March 2019.

5- Chris Cummings, (2015), The UK: Leading western Centre for Islamic Finance, ' The UK Islamic Finance Market' (https://www.londonstockexchange.com/specialist-issuers/islamic/islamicfinance2015.pdf) Accessed 17 March 2019.

6- Dawn, 'Gaping HR gap in Islamic finance industry' Sarwat Ahson, January 2016, (https://www.dawn.com/news/1230681) accessed 6 March 2019.

7- Finance Accreditation Agency, 'Issues and Challenges in Developing Human Resources in Islamic Finance' (https://www.faa.org.my/article/issues-and-challenges-in-developing-human-resources-in-islamic-finance) accessed 6 March 2019.

8- Finance Accreditation Agency, 'Issues and Challenges in Developing Human Resources in Islamic Finance' (https://www.faa.org.my/article/issues-and-challenges-in-developing-human-resources-in-islamic-finance) accessed 6 March 2019.

9- Gulf News Business,' Bridging the skills gap in Islamic finance' Tirad Al-Mahmoud, January 2016, (https:/gulfnews.com/business/banking/bridging-the-skills-gap-in-islamic-finance) accessed 3 January 2019.

10- Institute Bank-Bank of Malaysia, 'Study on Talent and Skills Requirements For the Banking Sector In Malaysia’ June 2014, (https://www.pwc.com/my/en/assets/publications) accessed 8 March 2019.

11- Malaysia World's Islamic Finance Marketplace, 'GROWING DEMAND FOR TALENT IN ISLAMIC FINANCE' June 2015, (http://www.mifc.com/index.php?ch=28\&pg=72\&ac=133\&bb=uploadpdf) Accessed 8 March 2019.

12- Naoel Chaouch, (2017), 'An Exploratory Study of Tunisian Customers' Awareness and Perception of Islamic Banks’ International Journal of Islamic Economics And Finance Studies, 3, 2, p 28.

13- Norhanim Dewa and Sabarudin Zakaria, (2012), 'Training and Development of Human Capital in Islamic Banking Industry’ Journal of Islamic Economics, Banking, and Finance, 8, 1, p 99.

14- Nurul Wajhi Ahmad, Murni Yunus Mawar, and Norazlina Ripain, (2017) 'The Exploration Study on Employability of Islamic Banking and Finance Graduates' Proceeding of the 4th International Conference on Management and Muamalah 2017 (ICoMM 2017), 641.

15- Sayd Farook and Mohammad Omar Farooq, (2013) 'Sharôñah Governance, Expertise and Profession: Educational Challenges in Islamic Finance’ ISRA International Journal of Islamic Finance, 5, 1, P 143.

16- Siti Khadijah Ab Manan, Rafeah Saidon, Amal Hayati Ishak, and Noorul Huda Sahari, 'COMPETENCY SKILLS OF GRADUATING ISLAMIC FINANCE STUDENTS' (2018) The Turkish Online Journal of Design, Art and Communication, 1424.

17- Tengku Wasimah Raja Harun, Rosemaliza Ab Rashid, and Abu Bakar Hamed, (2015) Factors Influencing Products' Knowledge of Islamic Banking Employees' Journal of Islamic Studies and Culture, 3, 1 p 25.

18- Zeti Akhtar Aziz, 'Talent development in Islamic finance over the next decade' (2011) KL (https://www.bis.org/review/r111222h.pdf) accessed 17 March 2019. 